\title{
The financial condition of selected enterprises from the Świętokrzyskie voivodeship during the COVID-19 pandemic - A survey analysis
}

Daria Moskwa-Bęczkowska

PhD, The Chair of Economy and Finance, The Faculty of Management and Computer Modelling, Kielce University of Technology, Poland.

Email: dariam@tu.kielce.pl

Keywords

Financial Condition, Financial Liquidity,

Enterprises, The COVID-19 Pandemic.

Article History

Received on $10^{\text {th }}$ October 2021

Accepted on $13^{\text {th }}$ November 2021

Published on $23^{\text {rd }}$ December 2021

Cite this article

Moskwa-Bęczkowska, D. (2021). The

financial condition of selected enterprises

from the Świętokrzyskie voivodeship during

the COVID-19 pandemic - A survey

analysis. Humanities \& Social Sciences

Reviews, 9(6), 46-50.

https://doi.org/10.18510/hssr.2021.968

Copyright @ Author

Publishing License

This work is licensed under a Creative Commons Attribution-Share Alike 4.0 International License

\section{Abstract}

Purpose of the study: This article aims to assess the financial condition of selected enterprises from the Świętokrzyskie Voivodeship during the ongoing COVID-19 pandemic.

Methodology: The article presents the results of proprietary surveys on the usefulness of the economic entities' cost accounting system to manage their costs in the conditions of the COVID-19 pandemic. These studies were carried out using the Computer-Assisted Web Interview method. Economic entities from the Świętokrzyskie voivodship with an entry in the National Court Register were invited to the survey via email. They were commercial law companies, mainly limited liability companies, joint-stock companies, etc.

Main Findings: The main conclusion from the conducted research is the statement that the difficult economic situation of the market sector in Poland does not always translate into the financial condition of enterprises. The common opinion about the financial problems of Polish companies caused by the COVID19 pandemic turns out to be wrong. The examined economic entities do not struggle with the issue of losing financial liquidity at all. On the contrary, over $40 \%$ of them indicated an improvement in the financial result in 2020 compared to 2019.

Applications of this study: The results of the conducted research confirm that the COVID-19 pandemic in Poland did not significantly worsen the financial situation of the surveyed business entities; on the contrary, the vast majority of them do not and have had no problems with maintaining financial liquidity.

The originality of this study: The analysis of the literature on the subject showed that there is no data on the assessment of the financial condition of enterprises in the conditions of the COVID-19 pandemic, taking into account at the same time the organizational and legal form of the studied entity and the area of its operation. 


\section{Kondycja finansowa wybranych przedsiębiorstw z województwa świętokrzyskiego w okresie pandemii wirusa COVID-19 - wyniki autorskich badań ankietowych \\ Daria Moskwa-Bęczkowska}

dr, Katedra Ekonomii i Finansów, Wydział Zarządzania i Modelowania Komputerowego, Politechnika Świętokrzyska, Polska.

Email: dariam@tu.kielce.pl

\begin{abstract}
Slowa kluczowe
kondycja finansowa, płynność finansowa, spółki prawa handlowego, pandemia Covid-19,

Historia artykułu

Otrzymano 10 października 2021

Przyjęta 13 listopada 2021

Opublikowano 23 grudnia 2021

\section{Cite this article}

Moskwa-Bęczkowska, D. (2021). The financial condition of selected enterprises from the Swiętokrzyskie voivodeship during the COVID-19 pandemic - A survey analysis. Humanities \& Social Sciences Reviews, 9(6), 46-50. https://doi.org/10.18510/hssr.2021.968
\end{abstract}

\section{Copyright @Author}

Publishing License

This work is licensed under a Creative Commons Attribution-Share Alike 4.0 International License

\begin{abstract}
Purpose of the study: Pandemia wirusa COVID-19 w znaczący sposób wpłynęła na funkcjonowanie zarówno gospodarek światowych, jak i gospodarki Polski. Niektóre podmioty zaczęły zmagać się z problemem terminowego regulowania bieżących zobowiązań. Zmuszone zostały do przeorganizowania sposobu prowadzenia działalności, dostosowując ją do szeregu ograniczeń wprowadzonych w związku z pandemią. Ograniczenia te wywołały duże wzburzenie wśród przedsiębiorców, którzy - mimo oferowanych im rządowych programów wsparcia - powszechnie demonstrowali swoje niezadowolenie. Celem niniejszego artykułu jest ocena kondycji finansowej wybranych przedsiębiorstw $\mathrm{z}$ województwa świętokrzyskiego w okresie trwającej pandemii wirusa COVID-19. Uzyskane wyniki dały podstawę do potwierdzenia bądź zaprzeczenia powszechnie funkcjonujących w tym zakresie opinii.
\end{abstract}

Methodology: W artykule przedstawione zostały wyniki autorskich badań ankietowych dotyczących oceny użyteczności systemu rachunku kosztów podmiotów gospodarczych dla potrzeb zarzadzania ich kosztami $w$ warunkach pandemii wirusa COVID-19. Badania te zostały przeprowadzone metodą ankiety wspomaganej komputerowo (Computer-Assisted Web Interview). Do badania, za pośrednictwem poczty elektronicznej, zaproszono podmioty gospodarcze z województwa świętokrzyskiego, posiadające wpis do Krajowego Rejestru Sądowego. Były to spółki prawa handlowego, w tym głównie spółki z ograniczoną odpowiedzialnością, spółki akcyjne, itp.

Main Findings: Głównym wnioskiem z przeprowadzonych badań jest stwierdzenie, iż trudna sytuacja ekonomiczna sektora rynkowego w Polsce nie zawsze przekłada się na kondycję finansową przedsiębiorstw. Powszechna opinia dotycząca problemów finansowych polskich przedsiębiorstw, spowodowanych pandemią wirusa COVID-19, okazuje się błędna. Badane podmioty gospodarcze wcale nie zmagają się $\mathrm{z}$ problemem utraty płynności finansowej. Wręcz przeciwnie ponad $40 \% \mathrm{z}$ nich wskazało na polepszenie wyniku finansowego $\mathrm{w}$ 2020 roku, w porównaniu z rokiem 2019.

Applications of this study: Wyniki przeprowadzonych badań stanowią potwierdzenie, iż pandemia wirusa COVID-19 w Polsce znacząco nie pogorszyła sytuacji finansowej badanych podmiotów gospodarczych, wręcz przeciwnie zdecydowana większość z nich nie ma i nie miała problemów z utrzymaniem płynności finansowej.

The originality of this study: Analiza literatury przedmiotu wykazała, iż brak jest danych na temat oceny kondycji finansowej przedsiębiorstw w warunkach pandemii wirusa COVID-19, uwzględniających jednocześnie formę organizacyjno-prawną badanego podmiotu oraz obszar jego funkcjonowania.

\section{WPROWADZENIE}

Pandemia wirusa COVID-19 istotnie wpłynęła i nadal wpływa na społeczno-ekonomiczne uwarunkowania funkcjonowania gospodarek światowych. Także i w Polsce jej skutki są wysoce odczuwalne dla podmiotów z sektorów publicznego i rynkowego. Wiele z nich musiało zareagować na zaistniałą sytuację, dostosowując specyfikę prowadzonej działalności do uwarunkowań wynikających z reżimu pandemicznego. Dla wielu przedsiębiorców niezwykle trudnym okresem był czas ubiegłorocznego lockdown-u, podczas którego musieli oni mocno ograniczyć zakres prowadzonych działań albo okresowo zaprzestać swojego funkcjonowania. Wprowadzone wówczas ograniczenia wzbudzały wiele obaw związanych - między innymi - z możliwością zachowania płynności finansowej przedsiębiorstwa oraz utrzymania stanu zatrudnienia na poziomie sprzed pandemii. Naprzeciw tym obawom stanęła antykryzysowa polityka rządu, w zakresie której uruchomione zostały finansowe programy wsparcia dla przedsiębiorstw. Ich celem było - chociaż częściowe - złagodzenie skutków wprowadzonych ograniczeń. 
Obecnie - po prawie dwóch latach od wybuchu pandemii - większość podmiotów sektora rynkowego dostosowała się do panujących w gospodarce warunków i radzi sobie relatywnie dobrze. Jak wynika z prowadzonych w tym zakresie badań w największej części dotyczy to średnich i dużych podmiotów w szczególności z sektora produkcyjnego Polski Instytut Ekonomiczny (2021).

Powyższe stwierdzenie potwierdzają także wyniki badań ankietowych przeprowadzonych przez autorkę niniejszego artykułu, którego celem jest ocena kondycji finansowej wybranych przedsiębiorstw z województwa świętokrzyskiego w czasie trwającej pandemii wirusa COVID-19.

\section{PRZEGLĄD LITERATURY}

Analiza i ocena kondycji finansowej przedsiębiorstwa jest podstawą sprawnego i skutecznego zarządzania. Dostarcza ona bowiem informacji o działalności podmiotu, które są niezwykle ważne w podejmowaniu bieżących i strategicznych decyzji gospodarczych Karmowska, Małecka (2009). Dobra kondycja finansowa jest kluczowa w prowadzeniu działalności gospodarczej, w szczególności, w sytuacjach trudnych i nieprzewidywalnych w skutkach, tak jak to się ma w przypadku trwającej pandemii wirusa COVID-19.

Problematyka charakterystyki kondycji finansowej podmiotów gospodarczych od dawna była przedmiotem rozważań licznych opracowań naukowych, np.: Bednarski (2007), Dudycz, Wrzosek (2000), Walczak (2007). Pojęcie kondycji finansowej przedsiębiorstwa w literaturze przedmiotu często określane jest mianem jego sytuacji finansowej, będącej rezultatem podejmowanych przez nie decyzji gospodarczych oraz związanych z tym szans jego rozwoju Siemińska (2002).

Jednym z warunków utrzymania dobrej kondycji finansowej przedsiębiorstwa jest zdolność do terminowego regulowania bieżących zobowiązań - która to w literaturze przedmiotu określana jest mianem płynności finansowej Ostrowska, Niedźwiecka (2015). Odgrywa ona duże znaczenie w okresie trwającej pandemii wirusa COVID-19 oraz wywołanego nią kryzysu gospodarczego. Szczególne uwarunkowania ekonomiczne funkcjonowania polskiej gospodarki sprawiają, iż w obecnym czasie wyjątkowo niebezpieczna jest utrata zdolności do terminowego wykonywania swoich wymagalnych zobowiązań pieniężnych. Dlatego też bieżące monitorowanie sytuacji finansowej przedsiębiorstwa jest kluczowe z punktu widzenia jego efektywnego funkcjonowania. Pozwala ono - między innymi - na szybkie wykrycie zagrożenia niewypłacalności oraz podjęcie stosownych działań naprawczych, w tym np.: pozyskiwania dodatkowych źródeł finansowania bądź podejmowania negocjacji z wierzycielami w celu odroczenia terminów płatności.

Jak wynika z przeprowadzonych w tym zakresie badań w czasie pandemii wiele podmiotów gospodarczych stara się chronić swą płynność finansową - między innymi - poprzez bieżący monitoring należności, pobieranie przedpłat, windykację należności, czy weryfikację kontrahentów przed nawiązaniem współpracy IMAS International (2021). Inne natomiast korzystały z rządowych programów wsparcia, kredytów i pożyczek, leasingu czy faktoringu. Według Polskiego Instytutu Ekonomicznego (w skrócie: PIE) obecna sytuacja polskich przedsiębiorstw jest wprawdzie trudna, ale i tak lepsza od prognozowanej na początku pandemii. Na podstawie, opracowanego przez PIE wspólnie z Bankiem Gospodarstwa Krajowego, wskaźnika Miesięcznego Indeksu Koniunktury (MIK) okazuje się, iż obawy przedsiębiorców zgłaszane na początku pandemii w większości się nie sprawdziły. I tak np.: na początku pandemii $27 \%$ badanych przedsiębiorstw deklarowało płynność finansową pozwalającą na przetrwanie powyżej trzech miesięcy, a obecnie na taką płynność wskazuje 53\% Polski Instytut Ekonomiczny (2021). Odmienne wyniki badań prezentuje Centrum Monitoringu Sytuacji Gospodarczej, według których przedsiębiorcy negatywnie oceniają kondycję finansową swoich firm. 19\% badanych podmiotów zadeklarowało, iż ich firma utraciła płynność finansową, 19\%, iż jest w stanie przetrwać nie dłużej niż 1 miesiąc Centrum Monitoringu Sytuacji Gospodarczej (2021). Niemniej jednak niezależnie od prezentowanych opinii nie ulega wątpliwości fakt, iż utrzymanie płynności finansowej firmy jest największym wyzywaniem z jakim przyszło się mierzyć przedsiębiorcom w okresie pandemii wirusa COVID-19 Krajowy Rejestr Długów (2021). Oczywiście należy w tym miejscu zaznaczyć, iż prezentowane badania były przeprowadzane zarówno w różnych okresach pandemii, jak i na różnych próbach badawczych co może mieć wpływ na sposób wnioskowania.

Mimo to przywołane wyniki badań potwierdzają rolę i znaczenie stabilnej kondycji finansowej w efektywnym zarządzaniu podmiotem gospodarczym, co oznacza, iż poruszana problematyka jest aktualna i ważna. Badania ankietowe przeprowadzone przez Autorkę niniejszego artykułu mogą zatem stanowić dopełnienie przedstawionych wyników, jak również stanowić inspirację do dalszej pracy w poruszanej problematyce.

\section{METODOLOGIA}

Autorka niniejszego artykułu w 2021 roku przeprowadziła autorskie badania ankietowe dotyczące oceny użyteczności systemu rachunku kosztów podmiotów gospodarczych dla potrzeb zarzadzania ich kosztami w warunkach pandemii wirusa COVID-19. Badanie przeprowadzone zostało z wykorzystaniem metody Computer-Assisted Web Interview czyli ankiety wspomaganej komputerowo. Kwestionariusz ankiety obejmował łącznie 23 pytania podzielone na trzy bloki tematyczne, w tym: charakterystykę badanego przedsiębiorstwa, ocenę jego działalności finansowej w warunkach pandemii wirusa COVID-19 oraz charakterystykę, stosowanego w tym podmiocie, rachunku kosztów. Zarówno ze względu na cel artykułu, jak i jego ograniczoną objętość w dalszej części przedstawione zostaną wyłącznie wyniki dotyczące oceny kondycji finansowej badanych przedsiębiorstw. 
Do badania zaproszonych zostało 2450 podmiotów z województwa świętokrzyskiego. Dane badanych przedsiębiorstw pozyskano z internetowej bazy Centralnego Ośrodka Informacji Gospodarczej, w której publikowane są dane teleadresowe firm posiadających wpis do Krajowego Rejestru Sądowego. Stąd też badaną grupą przedsiębiorstw są spółki prawa handlowego. Ze względu na fakt, iż zaproszenie do badania, jak i samo badanie ankietowe przeprowadzane było online, jednym z kryteriów doboru próby było posiadanie przez przedsiębiorstwo adresu e-mail.

W badaniu udział wzięło 1300 podmiotów, co stanowiło 53\% całej badanej populacji. Zdecydowaną większość, aż 70\% reprezentowały spółki z ograniczoną odpowiedzialnością, zatrudniające głównie do 9 pracowników. Najwięcej badanych podmiotów prowadzi swoją działalność w branżach produkcyjnej oraz usługowej, zaś najmniej w spożywczej oraz gastronomicznej.

\section{WYNIKI}

Wyniki przeprowadzonych badań w części odpowiadającej ocenie działalności finansowej badanych przedsiębiorstw w warunkach pandemii wirusa COVID-19 wskazują, iż sytuacja ta ma niewątpliwy wpływ na sposób ich funkcjonowania - por. dane zamieszczone na rysunku 1.

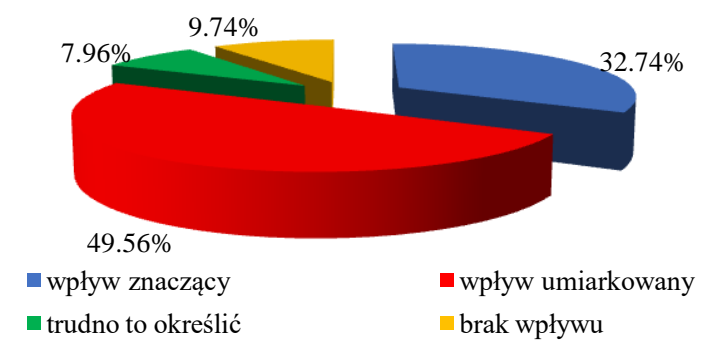

Rysunek 1: Ocena wpływu pandemii wirusa COVID -19 na funkcjonowanie badanych przedsiębiorstw

Źródło: Opracowanie własne.

Jak wynika w przedstawionych na rysunku 1 danych, zdecydowana większość przedsiębiorstw - ponad 80\% - uznała, iż trwająca w Polsce i na świecie pandemia znacząco (ok. 50\%) bądź umiarkowanie (ok. 33\%) wpłynęła na sposób ich funkcjonowania. Zgodnie z powszechnie formułowanymi opiniami mogłoby się wydawać, iż wpływ ten ma charakter negatywny. Jednakże z przeprowadzonych badań wynika, iż obecne uwarunkowania gospodarcze funkcjonowania sektora rynkowego w grupie badanych podmiotów nie zaskutkowały pogorszeniem ich kondycji finansowej. Przedsiębiorstwa zapytane o to jak zmienił się ich ogólny wynik finansowy w roku 2020 w porównaniu z rokiem 2019 odpowiedziały, iż nieznacznie wzrósł on w analizowanym okresie - rysunek 2.

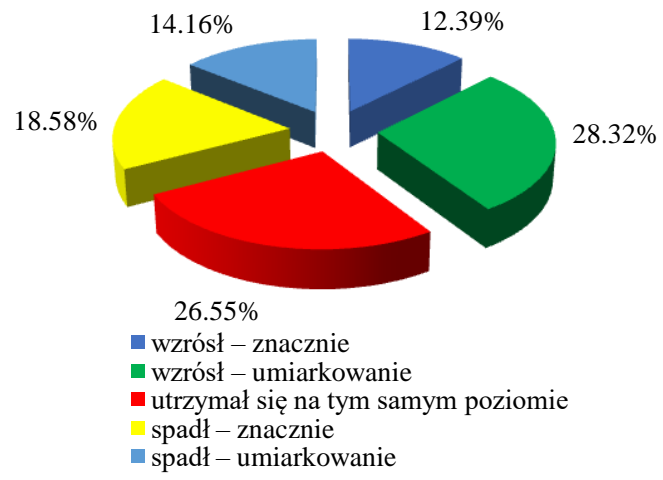

Rysunek 2: Relacja wyniku finansowego badanych przedsiębiorstw z roku 2019 do 2020

Źródło: Opracowanie własne.

Dodatnie wyniki finansowe wskazują zatem, iż badane przedsiębiorstwa - w przeważającej części - nie miały problemów z utrzymaniem płynności finansowej w swoim podmiocie. Potwierdziły to odpowiedzi na kolejne zadane im pytanie: czy w czasie trwającej pandemii mieli problemy z płynnością finansową? $60 \%$ ankietowanych przedsiębiorstw udzieliło odpowiedzi przeczącej, twierdząc, iż pandemia nie ma większego wpływu na płynność w ich firmie. Pozostałe $40 \%$ podmiotów wskazało jednak na pewne trudności finansowe w swoim podmiocie. U około $22 \% \mathrm{z}$ nich pojawiły się problemy z terminowym wpływem należności od kontrahentów, około $16 \%$ nie mogło uregulować swoich zobowiązań $\mathrm{w}$ terminie a blisko $10 \%$ - z różnych względów nie analizowanych bliżej w badaniu - utraciło swoich partnerów handlowych i klientów. Z kolei nieznaczna część badanych podmiotów - blisko $2 \%$ - rozważała zawieszenie prowadzonej działalności a nawet ogłoszenie upadłości. 
Bez względu na ogólną sytuację finansową przedsiębiorstwa, każde z nich musi obecnie funkcjonować w szczególnych warunkach spowodowanych pandemią wirusa COVID-19. Wymusza to zatem konieczność reorganizacji działalności przedsiębiorstwa w wielu obszarach jego funkcjonowania. Przedsiębiorstwa zapytane na jakie decyzje strategiczne w ich podmiocie ma wpływ pandemia wirusa COVID-19 najczęściej wymieniały konieczność przeorganizowania swojej działalności i dostosowania jej do istniejących warunków - ponad 38\% udzielanych odpowiedzi. Pozostałe odpowiedzi przedstawione zostały na rysunku 3.

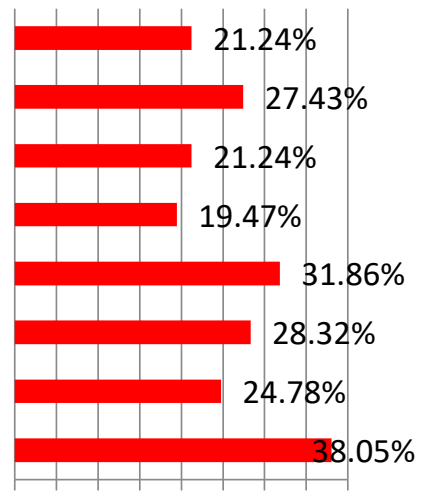

Rysunek 3: Decyzje strategiczne w przedsiębiorstwach podejmowane w okresie pandemii wirusa COVID-19

$$
\text { Źródło: Opracowanie własne. }
$$

Jak wynika z danych przedstawionych powyżej drugą najważniejszą decyzją w przedsiębiorstwie było ograniczenie jego wydatków (prawie 32\% podmiotów wskazało na tę odpowiedź), a co dalej za tym idzie zwrócenie większej uwagi na poziom i strukturę ponoszonych przez nie kosztów. Z punktu widzenia efektywnego prowadzenia działalności koszty własne przedsiębiorstwa są niezwykle istotną kategorią ekonomiczną a ich stała kontrola uwarunkowana jest wiarygodnym systemem rachunku kosztów. W ramach przeprowadzonych badań ankietowych dokonano także analizy użyteczności stosowanego w przedsiębiorstwie rachunku kosztów, jednakże jej wyniki przedstawione zostaną w odrębnym artykule.

\section{WNIOSKI}

Uzyskane wyniki badań potwierdzają tezę sformułowaną na początku rozważań, iż mimo trudnych uwarunkowań społeczno-gospodarczych spowodowanych pandemią wirusa COVID-19 zdecydowana większość badanych przedsiębiorstw nie utraciła swojej płynności finansowej. Oczywiście, jak wcześniej wspomniano, należy zwrócić uwagę na fakt, iż prezentowane w niniejszym artykule wyniki dotyczą wyłącznie podmiotów gospodarczych posiadających wpis do Krajowego Rejestru Sądowego, a swoją działalność prowadzą na terenie województwa świętokrzyskiego. To oznacza, iż prezentowane wnioski i opinie odnoszą się wyłącznie do tej grupy przedsiębiorstw. Dobra kondycja finansowa badanej grupy jest także wynikiem wsparcia finansowego w ramach Rządowych Tarcz Antykryzysowych. Wśród ankietowanych najczęściej wybieranymi formami wsparcia były subwencje Państwowego Funduszu Rozwoju, zwolnienia z ZUS czy dofinansowania do miejsc pracy. Niewykluczone zatem, iż utrzymanie płynności finansowej w badanych przedsiębiorstwach było możliwe - między innymi - dzięki otrzymanym dofinansowaniom.

\section{Bibliografia}

1. Bednarski L. (2007). Analiza finansowa w przedsiębiorstwie, PWE, Warszawa.

2. Centrum Monitoringu Sytuacji Gospodarczej (2020). Sytuacja ekonomiczna przedsiębiorstw w czasach koronawirusa. Raport z badania.

3. Dudycz T., Wrzosek S. (2000). Analiza finansowa. Problemy metodyczne w ujęciu praktycznym. Wyd. AE, Wrocław.

4. IMAS International (2021). Płynność finansowa MŚP w pandemii, Raport $\mathrm{z}$ badania.

5. Karmowska G, Małecka A. (2009). Ocena kondycji finansowej przedsiębiorstwa PGE. Ekonomika $i$ organizacja gospodarki żywnościowej, nr 76, 109-120.

6. Krajowy Rejestr Długów i firma faktoringowa NFG (2021). Płatności i finansowanie przedsiębiorstw w czasie pandemii. Raport z badania.

7. Ostrowska D., Niedźwiecka E (2015). Podstawy finansów przedsiębiorstw. Difin. Warszawa, s. 158.

8. Polski Instytut Ekonomiczny (2021). Miesięczny Indeks Koniunktury.

9. Siemińska E. (2002). Metody pomiaru i oceny kondycji finansowej przedsiębiorstwa. Wyd. Dom Organizatora, Torun.

10. Walczak M. (red.) (2007). Analiza finansowa w zarządzaniu współczesnym przedsiębiorstwem, Difin, Warszawa. 